\title{
Do Hindi Cinema \& Television Serials Propagate Caste Stereotypes through Surnames of Characters: A Content Analysis
}

\author{
Rakesh Kumar Maurya $^{1 *}$
}

\section{ABSTRACT}

Caste affiliated surnames are very common in India. In fact, they convey a lot of caste stereotypes about the bearer. This is a subtle way of practicing caste based identities and related discriminations. The current study is a content analysis of the surnames of leading fictional characters in Hindi TV serials and movies to see if TV and cinema propagate caste stereotypes through surnames of their fictional characters. The result shows excessive use of upper caste affiliated surnames used both in TV serials and cinema while surnames affiliated to lower castes have negligible presence in these programmes.

Keywords: Stereotype, Caste stereotype, Surname, Television, Hindi Cinema, Media.

The word 'Caste' is of European origin and it was first used by Purtgies travellers to India in the middle of fifteenth century. This word originated from Spanish word 'Casta' which means 'lineage’ or 'race’ or 'a group of people having hereditary quality'.(Srinivas, 1968; Ghurye, 1932).

Caste can be defined as hereditary endogamous group, having a common name, common traditional occupation, common culture, relatively rigid in matters of mobility, distinctiveness of status and forming a single homogeneous community.

In India, it is a system of social stratification which divides communities into thousands of endogamous hereditary groups called Jati. These jatis are grouped into four vernas: Brahmin, Kshatriya, Vaishya and Shudra. There is another group known as untouchables or Dalits who are ostracised from the four vernas. Social segregation in caste system is different from ethnic segregation which is based on the physical appearances. It is also different from other forms of social segregation based on material resources. It is based on purity and impurity of occupation where Brahmins are placed at the top of the ladder, Kshtriya below them, Vaishya and Shudra at the bottom.

\footnotetext{
${ }^{1}$ Doctoral student in Counselor Education and Supervision at University of Wyoming, U.S.A

*Responding Author

(C) 2016 I R Maurya; licensee IJIP. This is an Open Access Research distributed under the terms of the Creative Commons Attribution License (http://creativecommons.org/licenses/by/2.0), which permits unrestricted use, distribution, and reproduction in any Medium, provided the original work is properly cited.
} 


\section{Do Hindi Cinema \& Television Serials Propagate Caste Stereotypes through Surnames of Characters: A Content Analysis}

The most striking feature of caste in India is the superimposition of endogamy on exogamy (Ambedkar, 1968). A person from a particular caste is allowed to marry only within his caste (Endogamy) but is not allowed to marry within his gotra(Exogamy). Gotra, lineage segment within an Indian caste that prohibits intermarriage by virtue of the members' descent from a common mythical ancestor, is an important factor in determining possible Hindu marriage alliances (Encyclopedia Britannica, 2015).

\section{Surname: an extension of social identity and a subtle way of casteism in modern India}

"What's your name?"

"My name is Rakesh."

"And?"

"What?"

"I mean your surname?"

"I am Rakesh Maurya"

This conversation would seem innocuous for someone having little or no knowledge about Indian society. After all, what's wrong if someone asks your surname? Would it matter if I change the surname from Maurya to Mishra or something else? At least, in Indian society it would create a huge difference of perception. In India, your surname denotes your caste affiliation (Pandey, 2013). And if you do not have any surname, it is assumed that you belong to lower castes. Although, surnames are not a very reliable source of information, people rely on it to infer other person's caste and social position (Jogdand, 2013).

The use of caste specific surnames is very popular among those belonging to Brahmins, Kashtriya and Vaishya- the top three varna of Indian society. In Indian society, caste based identities are commonly used and among those identities surnames are the most popular. For example, people prefer to address others by their surnames and not by their first name. Identities based on surnames are a matter of pride among forward caste people and they often show it off (Jaffrelot, 2003; Babu, and Khare, eds., 2011), however, as we go down the social ladder, the uses of surname based identities are avoided by lower caste people particularly by Dalits. The reasons behind it are not difficult to decipher. For thousands of years, Dalits and low caste people have been denied social identities. For example: For hundreds of years, Dalits were not allowed to drink water from the common source of water like pond or well as their touch would pollute the water (Tiwary and Phansalkar, 2007). Even animals were allowed to drink water from the same source but not Dalits. The message was clear: they were considered worse than four legged animals. Their touch would pollute anything even their shadow would pollute others. This was clearly a denial of human identity. Also, the history of Dalits and other lower caste people is a history of thousands of years of servitude, exploitation and oppression on the basis of being born in a particular community or caste. On a more gruesome side, it is a reminder of being forced to live outside the village or town, have no access to schools, offices and temples 


\section{Do Hindi Cinema \& Television Serials Propagate Caste Stereotypes through Surnames of Characters: A Content Analysis}

(Kshīrasāgara, 1994). Therefore, surnames for a low caste or Dalit person is related to stigmatised caste identity.

“The communicative thrust of 'being asked about one's surname' is deeply related to stigmatized caste identity. In the hands of the upper castes, the banal act of 'being asked about one's surname' becomes a means of emphasizing devalued nature of identity and derogatory history. It also constitutes non-recognition of individual identity. In other words, the banal act by the upper castes is an effort to make Dalits ashamed about their individual and group identity. This often leads to feeling of humiliation among Dalits."(Jogdand, 2013)

Caste system in India still works at a subtle level even after 70 years of independence. Matrimonial sections in newspapers and many websites are testament to this practice. In fact, marriages are the time when you can see how caste practices function in Indian society. If you look at these advertisements, the social transactions happen and the currency used in these transactions is "Surname".

Caste system is different from racial segregation observed in western countries. Unlike race, there is not based on racial differences. In fact, one can not differentiate between people of various caste based on their outward appearance (Cox, 1945). Since, it is difficult to identify someone's caste by his/her physical appearance, people take help from surnames to infer an individual's caste affiliation. (Despandey, 2008)

There are many institutions and social organizations, whose names as well as work are to promote the welfare of that particular caste. Brahman Mahasabha, Kshatriya Honour Society, Kayasth Samaj etc are based on caste identity and their chief task is to promote welfare of a particular caste group. While there is no problem if these organizations promote welfare of their own people however by giving it a particular caste oriented names like Brahmin, Kshatriya, Kayastha etc, it does more harm by dividing society on caste lines. Many political parties, in India, have also been created on caste lines. Bahujan Samaj party, a dominant political force in north India, has clearly identified itself with schedule castes. Samajwadi party another dominant political force in Uttar Pradesh, has clear inclination towards a particular backward caste.

Surname in India is indicative of your caste and caste indicates your social and economic status. So surnames in India have a great value and people are very much interested in surnames.

\section{How Cinema \& Television influence our cognition and behaviour?}

Hindi Cinema and television are one of the most popular means of entertainment for people in north India. Apart from being entertained from these two powerful mediums, they influence our thinking and behaviour in both explicit and implicit ways. 


\section{Do Hindi Cinema \& Television Serials Propagate Caste Stereotypes through Surnames of Characters: A Content Analysis}

Cinema and television influence our life in a variety of ways. There are considerable evidence which suggest that visual media influence children in both positively as well as negatively. Albert Bandura's famous experiment of baby doll shows that children learn most of the things by simply observing their environment. Cinema and television also comes in the periphery of their observation. Research studies conducted by the most successful children programme on television " sesame street" shows how this medium can be harnessed for inculcating educational, cultural and moral values in children. A recent study conducted by University of Wiscosinmadison in 2013 by Marie-Louise Mares and Zhongdang Pan found significant positive effect of exposure to 'Sesame Street' across a number learning outcomes like social learning and health and safety knowledge.

There are considerable body of research which shows that visual media influence a wide range of attitudes and behaviours of young people. These studies have explored the impact of media on risk taking behaviours like engaging in sex, smoking, consuming alcohol, aggression, violence as well as other behaviour such as wearing trendy and fashionable clothes and mannerism.

Brown and Newcomer (1990) found that watching more sexual content on television increases the risk of engaging in teenage sexual intercourse. Also, a positive correlation was found between watching visual media with sexual content and permissive attitude of viewers towards pre-marital sex (Calfin, Carroll and Schmidt, 1993). Another study which compared pregnant and non-pregnant girls showed that pregnant girls are more likely to have been watching soap operas prior to pregnancy as compared to non-pregnant girls (Corder-Bolz, 1981). Another study linked early experiences of sex to watching visual media (Peterson and Kahn, 1984).

In their study on Impact of media on adolescent sexual attitudes and behaviours, Escobar-Chaves and her colleagues found that adolescents exposed to NC-17 rated films are more likely to have more than one sexual partner, having more negative attitude towards use of condom and engaging in sex more often. Brown et al. emphasized that sexually explicit media work as a sexual "super peer" for teenagers in the absence of proper counseling from family and school (Brown, Halpern and L'Engle, 2005). Brown et al. created an index known as 'sexual media diet' (SMD) to measure the sexual content in mass media. Their study revealed that white adolescent girls between 12 to 14 years in the top 20\% of the SMD density are more than twice likely to have had sexual intercourse as girls in the lower $80 \%$ of SMD density.

Smoking among youth is another area where effect of television and cinema is very much visible. Strong evidence of this effect has led the National Cancer Institute to officially declare a causal relationship between smoking in films \& television and starting of smoking among youth (National Cancer Institute, 2008). Another study by Heatherton and Sargent found that adolescent with high exposure to smoking in films are three times more susceptible to try smoking in real life as compared to those with low exposure. This effect remained significant 


\section{Do Hindi Cinema \& Television Serials Propagate Caste Stereotypes through Surnames of Characters: A Content Analysis}

even after controlling other variables like personality factors, parenting style and sociodemographics (Heatherton and Sargent, 2009). Cross- cultural studies have also confirmed this relationship between exposure to smoking in films and initiation of smoking among youth (Hanewinkel and Sargent, 2008).

There are considerable evidence which suggests relationship between exposure of alcohol consumption in films and television and Initiation of drinking alcohol among youth. Sargent et al. found, while controlling other social variables, significant relationship between watching alcohol consumption in films and its consumption among teen in U.S. (Sargent et al., 2006). A similar cross-sectional study also found the relationship between viewing alcohol use in films and initiation of drinking among US adolescents (Dalton et al., 2006).

Violence and aggression shown on television and films also influence our behaviour in real life. There are many research studies including detailed cross sectional and longitudinal studies which have concluded a very clear cause-and -effect relationship between violence shown in media and aggression in real life (Strasburger and Donnerstein, 1999). Another review of studies clearly demonstrated that "violent imagery has short-term effects on arousal, thoughts, and emotions, increasing the likelihood of aggressive or fearful behaviour." It also noted a strong influence of portrayal of violence in media on those who have a predisposition for aggressive behaviour because of personality or environmental factors (Browne and Hamilton-Giachritsis, 2005).

Television and cinema also influence youth's ideas of fashion and their choices of clothing and accessories. In a survey study examining the clothing choice of 478 adolescents studying in 6th, 9th and 12th grade in two mid-western schools in US found that black adolescents are more likely to be influenced by media than by family and friends. Further, it observed that media is twice as much influential on urban adolescents as compared to rural adolescents (Wilson and MacGillivray, 1998). Media has the potential to disseminate information on fashion, beauty and other related accessories, and can create positive images for youth in their social development (Schwartz, 2004).

\section{How Hindi Cinema and Television Propagating Caste Stereotypes by insinuating Surnames of Characters?}

As we have already discussed how television and cinema influence our thinking and behaviour in a subtle way; and how 'Surnames" are used to infer caste identities and related stereotypes; the current study tries to explore a new question. Do Hindi cinema and television serials propagate caste stereotypes through surnames of their characters? 


\section{METHOD:}

\section{Sample:}

The content for analysis was selected from both the mediums: Television Serials and Hindi Cinema. For television serials, four most popular T.V. channels were selected i.e. Star Plus, Colors, Sony, Zee TV. Reality Shows and Historical and biographical serials were excluded from the content as they are not fictional. All the serials currently (December 3, 2015) telecasted on Star Plus, Sony, Colors and Zee tv are selected for analysis. Since Star Plus is the most popular TV channel for tv sops, its previous popular sops are also included in the data. Total 45 serials and three leading characters' surnames from each were selected for analysis.

For Hindi cinema, all the movies released in 2013 and 2014 were selected for analysis. The list of movies was selected from Internet Movie Database (IMDb). Total 42 movies from 2013 and 64movies from 2014 were selected for surname analysis. (Appendix 1)

\section{Measures:}

Three main characters' surnames from television Hindi serials and movies were analysed to decipher whether they represent upper/forward caste, other backward caste, Muslim, SC/ST or 'no caste affiliation'. No caste affiliation' represents those names which do not carry any surname or using generic surnames (generic names are those which does not have any caste affiliation such as Anand ).To determine the caste affiliation of a particular surname, centre,s list of SC/ST and OBC as well as the plot of the story is used. The plot of the story is analysed from two sources: Wikipedia page of the sops/films and website of the channel.

\section{RESULT AND DISCUSSION:}

Out of 135 leading characters selected from 45 TV serials, 111 characters (82\%) carried a surname belonging to upper caste/general category, 6 characters (5\%) carried a surname belonging to Other Backward Classes (OBC), 6 characters (4\%) carried a surname belonging to Muslim and 12 characters (9\%) carried no surnames.

\begin{tabular}{|c|c|c|c|c|c|c|c|c|c|c|}
\hline \multicolumn{4}{|c|}{ Hindi Serials } & \multirow{2}{*}{ 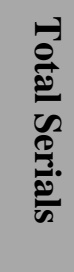 } & \multirow{2}{*}{ 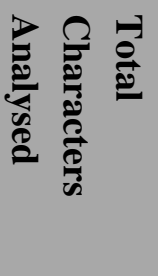 } & \multicolumn{5}{|c|}{ Caste/Category wise surnames } \\
\hline 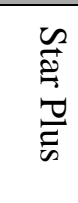 & $\begin{array}{l}\stackrel{N}{D} \\
\stackrel{D}{+} \\
\stackrel{+}{<}\end{array}$ & 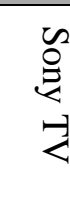 & $\frac{\Omega}{\frac{0}{0}}$ & & & 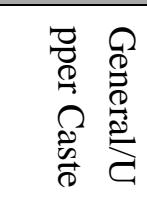 & 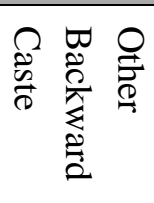 & $\stackrel{n}{\infty}$ & $\begin{array}{l}\text { 告 } \\
\text { 夏. }\end{array}$ & 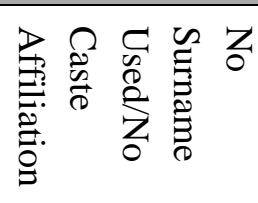 \\
\hline 25 & 11 & 2 & 7 & 45 & 135 & 111 & 6 & 0 & 6 & 12 \\
\hline
\end{tabular}

\section{Table-1}




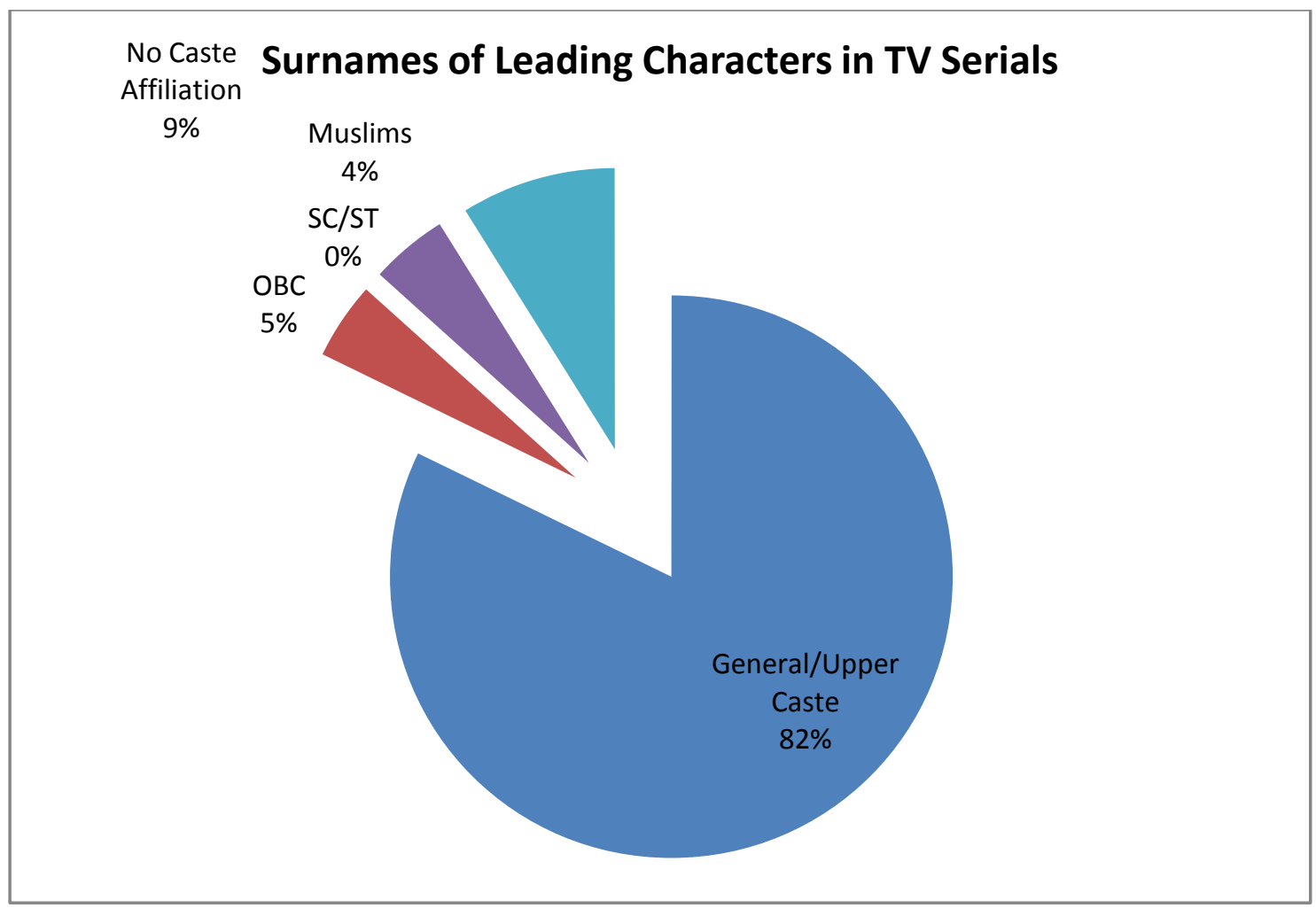

\section{Graph-1}

Out of 42 movies from 2013 and their 126 leading characters' surnames, 63 characters (50\%) carried a surname belonging to General/upper caste, 4 characters (3\%) carried a surname belonging to Other Backward Class (OBC), 15 characters (12\%) carried a surname belonging to Muslim and 44 characters(35\%) carried no surnames.

From 64 movies of 2014, 98 leading characters (51\%) carried surname belonging to General/Upper caste, 2 characters (1\%) carried surname belonging to Other Backward Classes(OBC), 21 characters (11\%) carried surname belonging to Muslims and 71 characters (37\%) did not carried any surname.

\begin{tabular}{|l|l|l|l|l|l|l|l|}
\hline \multirow{2}{*}{ Year } & \multirow{2}{*}{ Total Films } & \multicolumn{2}{|l|}{ Caste/Category wise surnames } \\
\cline { 3 - 8 } & & $\begin{array}{l}\text { Total } \\
\text { Characters }\end{array}$ & $\begin{array}{l}\text { General/Upper } \\
\text { Caste }\end{array}$ & $\begin{array}{l}\text { Other } \\
\text { Backward } \\
\text { Caste }\end{array}$ & SC/ST & Muslim & $\begin{array}{l}\text { No } \\
\text { Surname } \\
\text { used/Not } \\
\text { defined }\end{array}$ \\
\hline 2013 & 42 & 126 & 63 & 4 & 0 & 15 & 44 \\
\hline 2014 & 64 & 192 & 98 & 2 & 0 & 21 & 71 \\
\hline
\end{tabular}

Table-2 
Do Hindi Cinema \& Television Serials Propagate Caste Stereotypes through Surnames of Characters:

\section{Surnames of Leading Characters in Movies released in 2013}

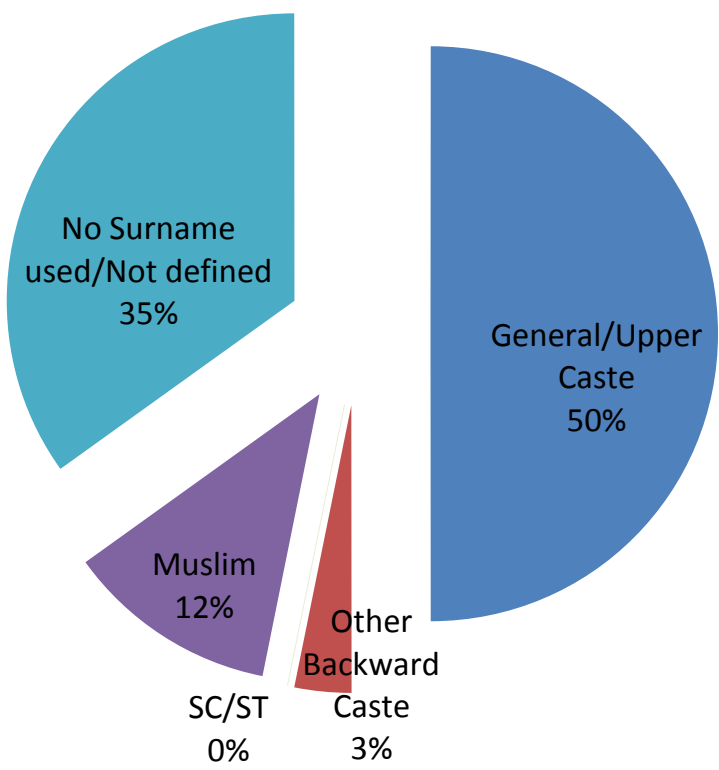

\section{Graph-2}

Surnames of Leading Characters in Movies released in 2014
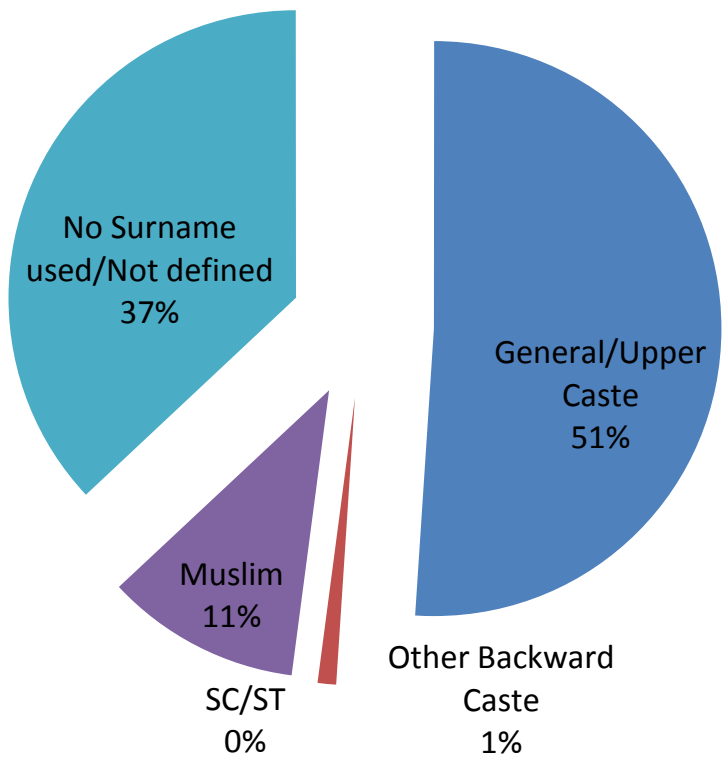

Graph-3

(c) The International Journal of Indian Psychology, ISSN 2348-5396 (e)| ISSN: 2349-3429 (p) | 164 


\section{Do Hindi Cinema \& Television Serials Propagate Caste Stereotypes through Surnames of Characters: A Content Analysis}

Looking at the data, it is clearly evident that surnames denoting forward caste affiliation are very popular among the story writers in Hindi Cinema/Serials. In Hindi television serials, this trend is very obvious: $82 \%$ characters carry a surname belonging to Forward caste. However, in movies it is close to $50 \%$ of all leading characters.

Surnames affiliated to Other Backward Castes are very few(5\% in tv serials and between $1 \%$ to $3 \%$ in movies.) keeping in mind that $\mathrm{OBC}$ are more than $1 / 3^{\text {rd }}$ of population of India.Not a single Surnames affiliated to SC/ST was found either in tv serials or movies. This is intriguing as SC/ST population is close to $20 \%$ of the country. In a fictional story where the author has the complete freedom to choose the surnames of its characters; why is there so much attachment with upper/forward caste surnames?

There could be various explanations to this anomaly. First; it shows the biased approach of writers at tv and cinema. Indian society still have strong notions of caste stereotypes, that is why a Bajrangi Bhaijaan- a devotee of Lord Hanuman in the movie Bajrangi Bhaijaan- has to be Pawan Kumar Chaturvedi and not Pawan Kumar Balmiki or Pawan Kumar Paswan. A business family in a tv serials has to have a character with surnames like Singhania, Mehra, Arora ( All forward caste surnames). Even a simple girl from a rural background has to be Arora/Mehra(Swaragini-Appendix 1). A research study was conducted by Gopal Sharan Sinha and Ramesh Chandra Sinha from Patna University on Caste Stereotypes in 1967. The researchers selected 200 students from Patna University through random sampling and administered a checklist containing 100 characteristics and a device to measure the preference for association to explore the stereotypes of 10 important castes in Bihar. The results showed a strong rhocoefficient correlation of 0.94 between caste stereotypes and preference of association.

Another argument supporting this overwhelming preference for upper/forward castes surnames is that cinema and television are the reflection of what's happening in society. Since, even in modern India, caste stereotypes are prevalent and widely implicitly /explicitly practised, the data of the current study should not be a surprise (Srinivasan, M., Dunham, Y., Hicks, C. and Barner, D., 2015).

Surnames with no caste affiliation consists of $9 \%$ characters in tv serials while in cinema, it is around 35\%.One possible explanation of this difference is that tv and cinema are different platforms in terms of their appeal and quality of manpower available to them. Cinema is a more creative, versatile and open platform where story writers, directors and producers try to serve unique products of entertainments for viewers while tv serials are based on concepts that are selling at the moment. Also, quality and experience of people working in tv serials are not as comprehensive as that of people working in cinema. 


\section{Do Hindi Cinema \& Television Serials Propagate Caste Stereotypes through Surnames of Characters: A Content Analysis}

Television and Cinema influence our cognition in a subliminal way even if we know that the story and characters are fictional. A message is called subliminal if it influences our cognition and thinking without our conscious awareness. Subliminal messages are commonly used in advertising where consumers are primed to purchase a particular product. In India, where caste affiliated surnames are used for social transactions, television serials and Hindi movies , even if they are fictional in nature, showing leading characters with upper castes surnames have the potential to propagate caste stereotypes.

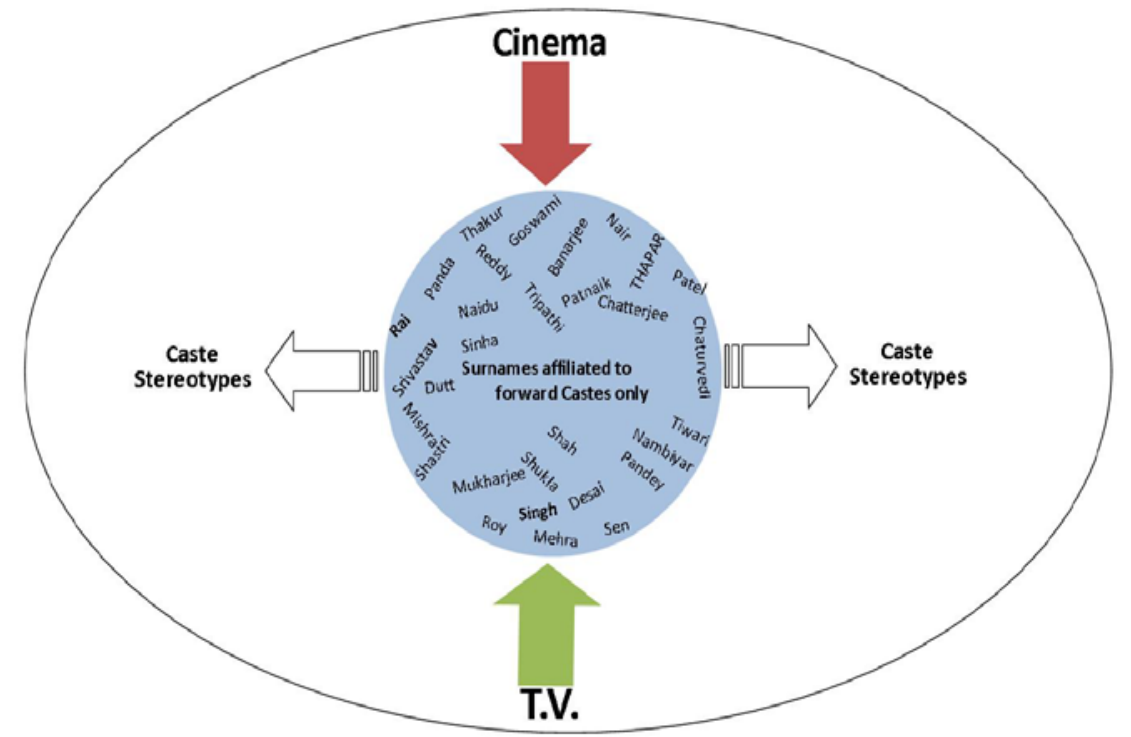

Fictional Characters in TV serials and Cinema having surnames affiliated to Forward Castes only would propagate Caste Stereotypes in society.

Caste stereotypes can be very damaging for individuals belonging to low caste or Dalits. A recent study, conducted by UC Burkley and published in Developmental Science, looks specifically at attitudes in India to Caste system suggests that "children and adults who were more influenced by caste were also more likely to believe that their own natural aptitude, academic success, and personality traits were fixed or set in stone.”(Srinivasan,2015). These attitudes need to be broken and Television and Cinema can play an effective role in breaking these attitudes and caste stereotypes. However, the current content analysis of television serials and cinema, instead of breaking those stereotypes, seem to be strengthening caste based stereotypes through surnames.

\section{The Way Ahead:}

Television is a very strong medium where almost all of us spend a few hours every day. One can imagine how strongly it propagates caste stereotypes among the masses through character's surname. Should we remove all the surnames from characters' name? Or should we keep surnames but make sure that all surnames from all social groups are represented in T.V. serials and movies? Or should we use generic surnames which denote no caste affiliation? During 1960s 


\section{Do Hindi Cinema \& Television Serials Propagate Caste Stereotypes through Surnames of Characters: A Content Analysis}

and 70s a revolution started in Tamilnadu to forsake the caste affiliated surnames. The dropping of the caste tags of Mudaliar, Nadar, Gounder, Thevar, Iyer, Pillai, Vanniyaretc., in the last few decades is a great social change that needs to be acknowledged and followed in all parts of the country(Ramadoss,2010). Having a caste free society is in the best interest of all. However, the way to achieve this goal could be many and there would be differences of opinions too. What we do in real life to address this complex issue should be debated among policy makers, however, in reel life, Broadcasting Content Complaints Council(BCCC) a self-regulatory body established by broadcasters, should take appropriate measures to address this caste stereotyping through characters' surnames. Also, Central Board of Film Certification (CBFC), a statutory body under Ministry of Information and Broadcasting should take appropriate measures to address the issue.

\section{CONCLUSION:}

The content analysis of surnames of leading characters of TV serials and cinema clearly shows that our story writers are biased in using surnames for their characters. Since surnames carries a lot of social insinuations, stereotypes and prejudices; projecting surnames of only forward castes in these programmes would propagate caste stereotypes among the viewers. Hence, using generic surnames or no surnames or proper representation of surnames of all castes should be used by story/script writers in serials and movies. Also, CBFC should also take this issue seriously and establish mechanism to deal with this caste bias with the help of character's surnames.

\section{REFERENCES:}

Ambedkar, B. (1968). Annihilation of Caste: With a Reply to Mahatma Gandhi, And, Castes in India: Their Mechanism, Genesis, and Development. Bheem Patrika Publications.

Babu, D. and Khare, R. eds. (2011). Caste in Life: Experiencing Inequalities. Pearson Education India.

Brown, J.and Newcomer, S. (1991). Television viewing and adolescents' sexual behaviour, Journal of Homosexuality 21:77-91.

Browne, K. and Hamilton-Giachritsis, C. (2005). The influence of violent media on children and adolescents: a public-health approach, Lancet 365:702-710.

Calfin, M., Carroll, J. and Schmidt, J. (1993). Viewing music-videotapes before taking a test of pre-marital sexual attitudes, Psychological Reports 72:475-481.

Corder-Bolz, C. (1981). Television and adolescents' sexual behaviour, Sex Education Coalition News 3:40.

Cox, O.C. (1945). Race and caste: A distinction. American Journal of Sociology, pp.360-368.

Dalton, M., Adachi-Mejia, A., Longacre, M. et al. (2006). Parental rules and monitoring of children's movie viewing associated with children's risk for smoking and drinking, Pediatrics 118:1932-1942.

Deshpande, A. (2008). 11 Caste and diversity in India. The Elgar companion to social economics, p.171. 


\section{Do Hindi Cinema \& Television Serials Propagate Caste Stereotypes through Surnames of Characters: A Content Analysis}

Encyclopedia Britannica. Gotra: Indian Caste System. Retrieved on Dec.10,2015 from http://www.britannica.com/topic/gotra

Ghurye, G. (1932). Caste and Race in India. London: Kegan Paul.

Hanewinkel, R. and Sargent, J.( 2008). Exposure to smoking in internationally distributed American movies and youth smoking in Germany: A cross-cultural cohort study, Pediatrics 121:e108-e117.

Heatherton,T. and Sargent, J. (2009). Does Watching Smoking in Movies Promote Teenage Smoking? Current Directions in Psychological Science 18(2):63-67.

Jaffrelot, C. (2003). India's silent revolution: the rise of the lower castes in North India. Orient Blackswan

Jogdand, Y. (2013). Humiliated by Caste:Understanding Emotional Consequences of Identity Denial. Retrieved from http://www.ispp.org/jsc/blog/humiliated-by- casteunderstanding-emotional-consequences-of-identity-denial

Kshīrasāgara, R. (1994). Dalit movement in India and its leaders, 1857-1956. MD Publications Pvt. Ltd.

Maurya, R. K. (2016). Use of Family Narratives as a Tool of Effective Parenting. The International Journal of Indian Psychology Vol.3(2) No.5, DIP: 18.01.091/20160302

Maurya, R.K. (2015). Advocacy Counseling in India: Current Scenario and the Road Ahead. Asian Academic Research Journal of Humanities and Social Sciences (AARJSH) Vol. 2(6), 233-254.

Maurya, R.K. (2015). Effective Parenting: A Master Key. Humanities and Social Science Studies (HSSS) Vol.4 (1), 23-28.

Maurya, R.K.,Singh, S. (2015). Traumatic Childhood Experiences and Stuttering: A Case Study. Asian Academic Research Journal of Humanities and Social Sciences(AARJSH) Vol.2(6), 331-351.

National Cancer Institute. (2008) .The role of the media in prompting and reducing tobacco use, NCI Tobacco Control Monograph No. 19. NIH Pub. No. 07-6242. Bethesda, MD.

NPTEL. Lecture 23: Caste System in India. Retrieved on Sept. 15,2015 from http://nptel.ac.in/courses/109103023/download/Lecture\%2023.pdf

Pandey, G. (2013). A history of prejudice: race, caste, and difference in India and the United States. Cambridge University Press.

Peterson, R. and Kahn, J. (1984). Media preferences of sexually active teens, Paper presented at the meeting of the American Psychological Association, 26 August 1984, Toronto, Canada.

Ramadoss, A.(2010, Aug.27). What is in a name? The Hindu. Retrieved from http://www.thehindu.com/todays-paper/tp-opinion/what-is-in-a-name/article597053.ece

Sargent, J., Wills, T., Stoolmiller, M. (2006). Alcohol use in motion pictures and its relation with early-onset teen drinking, Journal of Studies on Alcohol 67:54- 65.

Schwartz, K. (2004). The influence of wanting to look like media figures on adolescent physical activity, Journal of Youth Ministry 3(1):97-101. 


\section{Do Hindi Cinema \& Television Serials Propagate Caste Stereotypes through Surnames of Characters: A Content Analysis}

Sinha, G. and Sinha, R. (1967). Exploration in caste stereotypes. Social Forces, 46(1), pp.42-47. Srinivasan, M. (2015, March 31). Stereotypes persist that class and privilege determine intellect and success. Berkeley News. Retrieved from http://news.berkeley.edu/2015/03/31/castestereotypes/

Srinivasan, M., Dunham, Y., Hicks, C.M. and Barner, D. (2015). Do attitudes toward societal structure predict beliefs about free will and achievement? Evidence from the Indian caste system. Developmental science.

Strasburger, V. and Donnerstein, E. (1999). Children, adolescents, and the media: Issues and solutions, Pediatrics 103(1):129-139.

\section{APPENDIX 1}

The data about current television serials are taken from the websites of all TV channels including STAR PLUS, ZEE TV, COLORS and SONY. Total $45 \mathrm{tv}$ serials are selected for content analysis(Sony-2, Star Plus-25, Colors-7, Zee TV-11). All the serials currently (December 3, 2015) telecasted on Star Plus, Sony, Colors and Zee tv are selected for analysis.Since Star Plus is the most popular TV channel for tv sops, its previous popular sops are also included in the data.

To determine the caste affiliation of a particular surname, state/centre's list of SC/ST and OBC as well as the plot of the story is used. The plot of the story is analysed from two sources: Wikipedia page of the sops and website of the channel.

Caste affiliation is categorised in four categories.

1- General: Includes surnames affiliated to upper/forward castes

2- OBC: Includes surnames affiliated to Other Backward Castes

3- Muslim: Includes surnames affiliated to Muslims

4- SC/ST: Includes surnames affiliated to Dalits (SC/ST)

5- No caste affiliation: No surname used or generic surnames used.

\section{T.V. Serials}

\begin{tabular}{|c|c|c|c|c|c|}
\hline$\stackrel{\Omega}{\overparen{E}}$ & $\stackrel{\infty}{:-}$ & 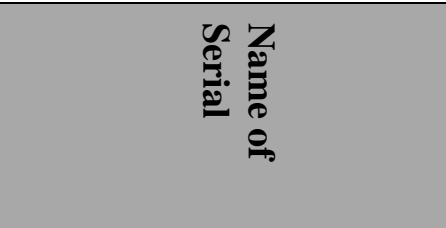 & 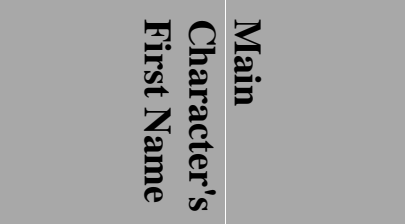 & 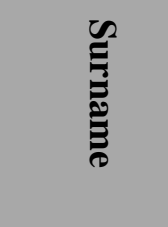 & 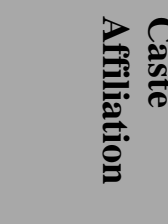 \\
\hline \multirow{3}{*}{ Sony } & \multirow{3}{*}{1} & \multirow{3}{*}{$\begin{array}{l}\text { Parvarrish - Kuchh Khattee } \\
\text { Kuchh Meethi }\end{array}$} & $\begin{array}{l}\text { Sweety Kaur Lakvinder } \\
\text { Singh }\end{array}$ & Ahluwalia & General \\
\hline & & & PinkyJeet & Ahuja & General \\
\hline & & & Rajesh Singh & Khanna & General \\
\hline \multirow{3}{*}{ Sony } & \multirow{3}{*}{2} & \multirow{3}{*}{ Pyaar Ko Ho Jaane Do } & Rizwan Ahmed & Khan & Muslim \\
\hline & & & Preet Ishaan & Hooda & General \\
\hline & & & Neeti & Khurana & General \\
\hline \multirow{4}{*}{$\begin{array}{l}\text { Star } \\
\text { Plus }\end{array}$} & \multirow{4}{*}{1} & \multirow{4}{*}{ Ye Hai Mohabbatein } & Raman & Bhalla & General \\
\hline & & & Shagun & Arora & General \\
\hline & & & Ruhi Raman Kumar & & \\
\hline & & & & Bhalla & General \\
\hline
\end{tabular}


Do Hindi Cinema \& Television Serials Propagate Caste Stereotypes through Surnames of Characters: A Content Analysis

\begin{tabular}{|c|c|c|c|c|c|}
\hline \multirow{3}{*}{$\begin{array}{l}\text { Star } \\
\text { Plus }\end{array}$} & \multirow{3}{*}{2} & \multirow{3}{*}{$\begin{array}{l}\text { Iss Pyaar Ko Kya Naam } \\
\text { Doon? }\end{array}$} & KhushiKumari & Gupta & OBC \\
\hline & & & Arnav Singh & Raizada & General \\
\hline & & & Anjali & Raizada & General \\
\hline \multirow{3}{*}{$\begin{array}{l}\text { Star } \\
\text { Plus }\end{array}$} & \multirow{3}{*}{3} & \multirow{3}{*}{ Diya Aur Baati Hum } & Sandhya Sooraj & Rathi & General \\
\hline & & & SoorajArun & Rathi & General \\
\hline & & & Zakir & Siddiqui & Muslim \\
\hline \multirow{3}{*}{$\begin{array}{l}\text { Star } \\
\text { Plus }\end{array}$} & \multirow{3}{*}{4} & \multirow{3}{*}{ Yeh Rishta Kya Kehlata Hai } & AksharaNaitik & Singhania & General \\
\hline & & & Naitik Raj Shekhar & Singhania & General \\
\hline & & & Tara & Shekhawat & General \\
\hline \multirow{3}{*}{$\begin{array}{l}\text { Star } \\
\text { Plus }\end{array}$} & \multirow{3}{*}{5} & \multirow{3}{*}{ Sumit Sambhal Lega } & Sumit & Walia & General \\
\hline & & & Maya & Walia & General \\
\hline & & & Alia & Walia & General \\
\hline \multirow{3}{*}{$\begin{array}{l}\text { Star } \\
\text { Plus }\end{array}$} & \multirow{3}{*}{6} & \multirow{3}{*}{$\begin{array}{ll}\text { Phir } \quad \text { Bhi } & \mathrm{Na} \\
\text { Maane...Badtameez Dil } & \end{array}$} & Abeer & Malhotra & General \\
\hline & & & Meher & Purohit & General \\
\hline & & & Nissar & Malik & Muslim \\
\hline \multirow{3}{*}{$\begin{array}{l}\text { Star } \\
\text { Plus }\end{array}$} & \multirow{3}{*}{7} & \multirow{3}{*}{ Saath Nibhaana Saathiya } & Gopi & Modi & OBC \\
\hline & & & Meera & $\begin{array}{l}\text { Suryayansh } \\
\text { i } \\
\end{array}$ & General \\
\hline & & & Paridhi & Modi & OBC \\
\hline \multirow{3}{*}{$\begin{array}{l}\text { Star } \\
\text { Plus }\end{array}$} & \multirow{3}{*}{8} & \multirow{3}{*}{ Mere Angne Mein } & Shanti Devi & Shrivastav & General \\
\hline & & & Sarla & Aggarwal & General \\
\hline & & & Riya Shivam & Shrivastav & General \\
\hline \multirow{3}{*}{$\begin{array}{l}\text { Star } \\
\text { Plus }\end{array}$} & \multirow{3}{*}{9} & \multirow{3}{*}{ Tere Sheher Mein } & Amaya & Mathur & General \\
\hline & & & Sneha & Mathur & General \\
\hline & & & Ramashrey & Gupta & OBC \\
\hline \multirow{3}{*}{$\begin{array}{l}\text { Star } \\
\text { Plus }\end{array}$} & \multirow{3}{*}{10} & \multirow{3}{*}{ Suhani Si Ek Ladki } & SuhaniYuvraj & Birla & General \\
\hline & & & Soumya Krishna & Mishra & General \\
\hline & & & Krishna & Mishra & General \\
\hline \multirow{3}{*}{$\begin{array}{l}\text { Star } \\
\text { Plus }\end{array}$} & & 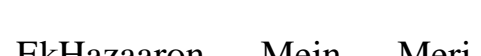 & JeevikaViren Singh & Vadhera & General \\
\hline & 11 & $\begin{array}{l}\text { EkHazaaron Mein Merı } \\
\text { Behn Hai }\end{array}$ & ManviVirat Singh & Vadhera & General \\
\hline & & & Viren Singh & Vadhera & General \\
\hline & & & Madhavan & Venkat & General \\
\hline $\begin{array}{l}\text { Star } \\
\text { Plus }\end{array}$ & 12 & $\begin{array}{l}\text { Kucnion hal rere } \\
\text { Darmivaan }\end{array}$ & KoyalMadhavan & Venkat & General \\
\hline & & & Vidya & Venkat & General \\
\hline & & & $\begin{array}{l}\text { SaraswatichandraLaxmi } \\
\text { nandan }\end{array}$ & Vyas & General \\
\hline & & & $\begin{array}{l}\text { KumudSundariSaraswati } \\
\text { chandra }\end{array}$ & Vyas & General \\
\hline $\begin{array}{l}\text { Star } \\
\text { Plus }\end{array}$ & 13 & Saraswatichandra & & $\begin{array}{l}\text { Dharmadhi } \\
\text { kari }\end{array}$ & \\
\hline & & & PramadDhan & & General \\
\hline
\end{tabular}


Do Hindi Cinema \& Television Serials Propagate Caste Stereotypes through Surnames of Characters: A Content Analysis

\begin{tabular}{|c|c|c|c|c|c|}
\hline \multirow{3}{*}{$\begin{array}{l}\text { Star } \\
\text { Plus }\end{array}$} & \multirow{3}{*}{14} & \multirow{3}{*}{$\begin{array}{ll}\text { Dosti... } & \text { Yaariyan... } \\
\text { Manmarziyan } & \end{array}$} & Radhika & Mishra & General \\
\hline & & & Samaira & Khanna & General \\
\hline & & & Arjun & Mehra & General \\
\hline \multirow{3}{*}{$\begin{array}{l}\text { Star } \\
\text { Plus }\end{array}$} & \multirow{3}{*}{15} & \multirow{3}{*}{ Tu Mera Hero } & Ashish & Agarwal & General \\
\hline & & & Panchi & Agarwal & General \\
\hline & & & Govindnarayan & Agarwal & General \\
\hline \multirow{3}{*}{$\begin{array}{l}\text { Star } \\
\text { Plus }\end{array}$} & \multirow{3}{*}{16} & \multirow{3}{*}{$\begin{array}{l}\text { Pyaar Ka Dard Hai Meetha } \\
\text { Meetha Pyaara Pyaara }\end{array}$} & Pankhuri Aditya & Kumar & $\mathrm{OBC}$ \\
\hline & & & Aditya Harish & Kumar & $\mathrm{OBC}$ \\
\hline & & & AnujPurushottam & Deewan & General \\
\hline \multirow{3}{*}{$\begin{array}{l}\text { Star } \\
\text { Plus }\end{array}$} & \multirow{3}{*}{17} & \multirow{3}{*}{$\begin{array}{l}\text { Navya..Naye Dhadkan Naye } \\
\text { Sawaal }\end{array}$} & Deepak & Mishra & General \\
\hline & & & Neeta & Mishra & General \\
\hline & & & NavyaAnant & Bajpai & General \\
\hline \multirow{3}{*}{$\begin{array}{l}\text { Star } \\
\text { Plus }\end{array}$} & \multirow{3}{*}{18} & \multirow{3}{*}{ Veera } & VeeraBaldev & Singh & General \\
\hline & & & RanvijaySampooran & Singh & General \\
\hline & & & BaldevBalwant & Singh & General \\
\hline \multirow{3}{*}{$\begin{array}{l}\text { Star } \\
\text { Plus }\end{array}$} & \multirow{3}{*}{19} & \multirow{3}{*}{ Ek Hasina Thi } & Durga & Thakur & General \\
\hline & & & Nitya & Mitra & General \\
\hline & & & Dev Arnab & Goenka & General \\
\hline \multirow{3}{*}{$\begin{array}{l}\text { Star } \\
\text { Plus }\end{array}$} & \multirow{3}{*}{20} & \multirow{3}{*}{$\begin{array}{l}\text { Mohi - Ek Khwab Ke Khilne } \\
\text { Ki Kahani }\end{array}$} & Mohi & & $\begin{array}{l}\text { No Caste } \\
\text { Affiliation }\end{array}$ \\
\hline & & & Ayush & & $\begin{array}{l}\text { No Caste } \\
\text { Affiliation }\end{array}$ \\
\hline & & & Anusha & & $\begin{array}{l}\text { No Caste } \\
\text { Affiliation }\end{array}$ \\
\hline \multirow{3}{*}{$\begin{array}{l}\text { Star } \\
\text { Plus }\end{array}$} & \multirow{3}{*}{21} & \multirow{3}{*}{$\begin{array}{l}\text { Mohi - Ek Khwab Ke Khilne } \\
\text { Ki Kahani }\end{array}$} & Pratigya Krishna & Singh & General \\
\hline & & & Thakur Krishna Sajjan & Singh & General \\
\hline & & & KomalKartik & Saxena & General \\
\hline \multirow{3}{*}{$\begin{array}{l}\text { Star } \\
\text { Plus }\end{array}$} & \multirow{3}{*}{22} & \multirow{3}{*}{ Sasural Genda Phool } & Suhana & Kashyap & OBC \\
\hline & & & Ishaan & Kashyap & $\mathrm{OBC}$ \\
\hline & & & Kamal Kishore & Bajpai & General \\
\hline \multirow{3}{*}{$\begin{array}{l}\text { Star } \\
\text { Plus }\end{array}$} & & & NishaKabir & Kumar & \\
\hline & 23 & Nisha Aur Uske Cousins & Viraj Singh & Rathore & General \\
\hline & & & Suketu Ramesh & Gangwal & General \\
\hline & & & Prerna & Sharma & General \\
\hline $\begin{array}{l}\text { Star } \\
\text { Plus }\end{array}$ & 24 & Kasautii Zindagii Kay & Anurag & Basu & General \\
\hline & & & Rishabh & Bajaj & General \\
\hline & & & Govardhan & Virani & General \\
\hline $\begin{array}{l}\text { Star } \\
\text { Plus }\end{array}$ & 25 & $\begin{array}{l}\text { Kyunkı Saas Bnı Kabnı Banu } \\
\text { Thi }\end{array}$ & AmbaGovardhan & Virani & General \\
\hline & & & Tulsi & Virani & General \\
\hline
\end{tabular}


Do Hindi Cinema \& Television Serials Propagate Caste Stereotypes through Surnames of Characters: A Content Analysis

\begin{tabular}{|c|c|c|c|c|c|}
\hline \multirow{3}{*}{ Colors } & \multirow{3}{*}{1} & \multirow{3}{*}{ Swaragini } & SwaraSanskaar & Maheshwari & General \\
\hline & & & Sanskaar Ram Prasad & Maheshwari & General \\
\hline & & & Sharmishtha & Gadodia & General \\
\hline \multirow{3}{*}{ Colors } & \multirow{3}{*}{2} & \multirow{3}{*}{ Sasural Simar Ka } & Siddhant & Bharadwaj & General \\
\hline & & & SiddhantRajendra & Bharadwaj & General \\
\hline & & & SimarPrem & Bharadwaj & General \\
\hline \multirow{4}{*}{ Colors } & \multirow{4}{*}{3} & \multirow{4}{*}{ Meri Aashiqui Tum Se Hi } & Milan Kailash & Vaghela & General \\
\hline & & & IshaniRanveer & Vaghela & General \\
\hline & & & Shikhar Raj Narayan & Mehra & General \\
\hline & & & DevarshMitesh & Parekh & General \\
\hline \multirow{3}{*}{ Colors } & \multirow{3}{*}{4} & \multirow{3}{*}{ Udann } & Kamal Narayan & Rajvanshi & General \\
\hline & & & Chakor & & No Caste Affiliation \\
\hline & & & Chunni & & No Caste Affiliation \\
\hline \multirow{3}{*}{ Colors } & \multirow{3}{*}{5} & \multirow{3}{*}{ Thapki Pyar Ki } & ThapkiBihaan & Pandey & General \\
\hline & & & BihaanBalvinder & Pandey & General \\
\hline & & & Shubh & Chaturvedi & General \\
\hline \multirow{3}{*}{ Colors } & \multirow{3}{*}{6} & \multirow{3}{*}{ Ishq Ka Rang Safed } & Viplav & Tripathi & General \\
\hline & & & Dashrath & Tripathi & General \\
\hline & & & Dhaani & & No Caste Affiliation \\
\hline \multirow{3}{*}{ Colors } & \multirow{3}{*}{7} & \multirow{3}{*}{ Naagin } & Ritik & Raheja & General \\
\hline & & & Yamini & Raheja & General \\
\hline & & & Tanvi & Mathur & General \\
\hline \multirow{3}{*}{ Zee T.V. } & \multirow{3}{*}{1} & \multirow{3}{*}{ Kumkum Bhagya } & Abhishek Prem & Mehra & General \\
\hline & & & Pragya & Arora & General \\
\hline & & & Daljeet & Mehra & General \\
\hline \multirow{3}{*}{ Zee T.V. } & \multirow{3}{*}{2} & \multirow{3}{*}{ Jamai Raja } & Siddharth & Khurana & General \\
\hline & & & Durga Devi & Patel & General \\
\hline & & & RoshniSiddharth & Khurana & General \\
\hline \multirow{3}{*}{ Zee T.V. } & & & Vishwaveer & Jha & General \\
\hline & 3 & Kaala Teeka & Gauri & Jha & General \\
\hline & & & JethiMaa & & No Caste Affiliation \\
\hline & & & Vihaan & Vatsal & General \\
\hline Zee T.V. & 4 & Satrangi Sasural & Kaira Vihaan & Vatsal & General \\
\hline & & & Neelima & Tripathi & General \\
\hline & & & RanaIndravadan & Singh Deo & General \\
\hline Zee T.V. & 5 & Ek Tha Raja Ek Thi Rani & Rani Gayatri & Devi & General \\
\hline & & & Rani Sulakshana & & General \\
\hline
\end{tabular}


Do Hindi Cinema \& Television Serials Propagate Caste Stereotypes through Surnames of Characters: A Content Analysis

\begin{tabular}{|c|c|c|c|c|c|}
\hline \multirow{3}{*}{ Zee T.V. } & \multirow{3}{*}{6} & \multirow{3}{*}{ Sarojini } & Sarojini & Singh & General \\
\hline & & & Somendra & Singh & General \\
\hline & & & Dushyant & Singh & General \\
\hline \multirow{3}{*}{ Zee T.V. } & \multirow{3}{*}{7} & \multirow{3}{*}{ Tashan-e-Ishque } & Twinkle Kunj & Sarna & General \\
\hline & & & Kunj Manohar & Sarna & General \\
\hline & & & Yuvraj & Luthra & General \\
\hline \multirow{3}{*}{ Zee T.V. } & \multirow{3}{*}{8} & \multirow{3}{*}{ Ye Vaada Raha } & Shrikant & & No Caste Affiliation \\
\hline & & & Survi & & No Caste Affiliation \\
\hline & & & Kartik & & No Caste Affiliation \\
\hline \multirow{3}{*}{ Zee T.V. } & \multirow{3}{*}{9} & \multirow{3}{*}{ Lajwanti } & Sunderlal & Bharadwaj & General \\
\hline & & & Lajwanti & Bharadwaj & General \\
\hline & & & Jamal & & Muslim \\
\hline \multirow{3}{*}{ Zee T.V. } & \multirow{3}{*}{10} & \multirow{3}{*}{ Neeli Chatriwaale } & Bhagwan Das & Chaubey & General \\
\hline & & & Gowardhan & Dubey & General \\
\hline & & & Mahadev & Singh & General \\
\hline \multirow{3}{*}{ Zee T.V. } & \multirow{3}{*}{11} & \multirow{3}{*}{ Qubool Hai } & Mahira & Akhtar & Muslim \\
\hline & & & Armaan Raza & Sheikh & Muslim \\
\hline & & & NayiSanam Nasir & Khan & Muslim \\
\hline
\end{tabular}

\section{Movies Released in 2013}

\begin{tabular}{|c|c|c|c|c|}
\hline 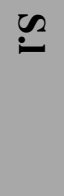 & 光 & 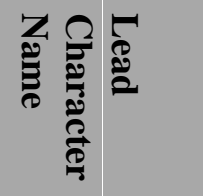 & 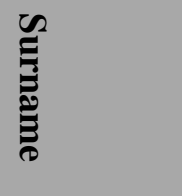 & 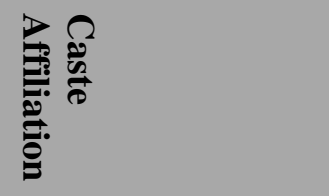 \\
\hline \multirow{3}{*}{1} & \multirow{3}{*}{ Once Upon a Time in Mumbaai } & Sultan & Mirza & Muslim \\
\hline & & Shoaib & Khan & Muslim \\
\hline & & Rehana & Shergill & General \\
\hline \multirow{3}{*}{2} & \multirow{3}{*}{ Chashme Baddoor } & Siddharth & Kashyap & OBC \\
\hline & & Omkar & Sharma & General \\
\hline & & Jai & Lakhanpal & No Caste Affiliation \\
\hline \multirow{3}{*}{3} & \multirow{3}{*}{ ShuddhDesi Romance } & Raghu Ram & & No Caste Affiliation \\
\hline & & Gayatri & & No Caste Affiliation \\
\hline & & Tara & & No Caste Affiliation \\
\hline \multirow{3}{*}{4} & \multirow{3}{*}{ Bullett Raja } & Raja & Mishra & General \\
\hline & & Rudra & Tripathi & General \\
\hline & & Ram Babu & Shukla & General \\
\hline \multirow{3}{*}{5} & \multirow{3}{*}{ Murder 3} & Vikram[ & & No Caste Affiliation \\
\hline & & Roshni & & No Caste Affiliation \\
\hline & & Nisha & & No Caste Affiliation \\
\hline
\end{tabular}


Do Hindi Cinema \& Television Serials Propagate Caste Stereotypes through Surnames of Characters: A Content Analysis

\begin{tabular}{|c|c|c|c|c|}
\hline \multirow{3}{*}{6} & \multirow{3}{*}{ Jolly LLB } & Jagdish & Tyagi & General \\
\hline & & Tejinder & Rajpal & No Caste Affiliation \\
\hline & & Sunderlal & Tripathi & General \\
\hline \multirow{3}{*}{7} & \multirow{3}{*}{ Phata Poster Nikhla Hero } & Vishwas & Rao & $\mathrm{OBC}$ \\
\hline & & Kajal & & No Caste Affiliation \\
\hline & & Savitri & & No Caste Affiliation \\
\hline \multirow{3}{*}{8} & \multirow{3}{*}{ Satyagraha } & Dwarka & Anand & No Caste Affiliation \\
\hline & & Manav & Raghvendra & No Caste Affiliation \\
\hline & & Yasmin & Ahmed & Muslim \\
\hline \multirow{3}{*}{9} & \multirow{3}{*}{ NautankiSaala } & Ram & Parmar & General \\
\hline & & Nandini & Patel & General \\
\hline & & Mandar & Lele & No Caste Affiliation \\
\hline \multirow{3}{*}{10} & \multirow{3}{*}{ R. Rajkumar } & Romeo & Rajkumar & No Caste Affiliation \\
\hline & & Chanda & & No Caste Affiliation \\
\hline & & Shivraj & Gurjar & General \\
\hline \multirow{3}{*}{11} & \multirow{3}{*}{ Kai PO Che } & Ishaan & Bhatt & General \\
\hline & & Omkar & Shastri & General \\
\hline & & Govind & Patel & General \\
\hline \multirow{3}{*}{12} & \multirow{3}{*}{ Fukrey } & Vikas & Gulaati & General \\
\hline & & Zafar & & Muslim \\
\hline & & Lali & & No Caste Affiliation \\
\hline \multirow{3}{*}{13} & \multirow{3}{*}{ Inkaar } & Rahul & Verma & OBC \\
\hline & & Maya & Luthra & General \\
\hline & & Mrs. Kamdhar & Kamdhar & General \\
\hline \multirow{3}{*}{14} & \multirow{3}{*}{ Matru Ki Bijlee Ka Mandola } & Harphool Singh & Mandola & No Caste Affiliation \\
\hline & & Hukum Singh & Matru & No Caste Affiliation \\
\hline & & Bijlee & Mandola & No Caste Affiliation \\
\hline \multirow{3}{*}{15} & \multirow{3}{*}{ Table No. 21} & Abdul Razaq & Khan & Muslim \\
\hline & & Vivaan & Agasthi & General \\
\hline & & Siya & Agasthi & General \\
\hline \multirow{3}{*}{16} & \multirow{3}{*}{ Zila Ghaziabad } & Thakur Pritam & Singh & General \\
\hline & & MahendraFauji & Baisla & General \\
\hline & & SatbirBaisla & Gurjar & General \\
\hline \multirow{3}{*}{17} & \multirow{3}{*}{ Raanjhanaa } & Kundan & Shankar & General \\
\hline & & Zoya & Haider & Muslim \\
\hline & & Jasjeet Singh & Shergill & General \\
\hline \multirow{3}{*}{18} & \multirow{3}{*}{ Boss } & Surya & & No Caste Affiliation \\
\hline & & Satyakant & Shastri & General \\
\hline & & Ayushman & Thakur & General \\
\hline 10 & YohJayaวni Hai Doowani & Naina & Talwar & General \\
\hline 15 & 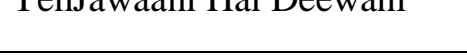 & Kabir & Thapar & General \\
\hline
\end{tabular}


Do Hindi Cinema \& Television Serials Propagate Caste Stereotypes through Surnames of Characters: A Content Analysis

\begin{tabular}{|c|c|c|c|c|}
\hline & & Aditi & Mehra & General \\
\hline \multirow[b]{3}{*}{20} & \multirow{3}{*}{ Dhoom 3} & Sahir & Khan & Muslim \\
\hline & & Aaliya & & No Caste Affiliation \\
\hline & & Jai & Dixit & General \\
\hline \multirow{3}{*}{21} & \multirow{3}{*}{ Chennai Express } & Meenalochni & Azhagusundaram & No Caste Affiliation \\
\hline & & Rahul & Mithaiwala & No Caste Affiliation \\
\hline & & Durgeshwara & Azhagusundaram & No Caste Affiliation \\
\hline \multirow{3}{*}{22} & \multirow{3}{*}{ Aashiqui 2} & Rahul & Jaykar & General \\
\hline & & AarohiKeshav & Shirke & General \\
\hline & & Vivek & & No Caste Affiliation \\
\hline \multirow{3}{*}{23} & \multirow{3}{*}{ Special 26} & Ajay "Ajju" & Singh & General \\
\hline & & Waseem & Khan & Muslim \\
\hline & & P. K. & Sharma & General \\
\hline \multirow{3}{*}{24} & \multirow{3}{*}{ Krrish 3} & Rohit & Mehra & General \\
\hline & & Kaal & & No Caste Affiliation \\
\hline & & Priya & Mehra & General \\
\hline \multirow{3}{*}{25} & \multirow{3}{*}{ The Lunch Box } & Saajan & Fernandes & General \\
\hline & & Shaikh & & Muslim \\
\hline & & Illa & & No Caste Affiliation \\
\hline \multirow{3}{*}{26} & \multirow{3}{*}{ Grand Masti } & Amar & Saxena & General \\
\hline & & Meet & Mehta & General \\
\hline & & Prem & Chawla & General \\
\hline \multirow{3}{*}{27} & \multirow{3}{*}{ D Day } & RudraPratap & Singh & General \\
\hline & & Zoya & Rehman & Muslim \\
\hline & & Wali & Khan & Muslim \\
\hline \multirow{3}{*}{28} & \multirow{3}{*}{ Vishwaroopam } & Wisam Ahmad & Kashmiri & Muslim \\
\hline & & Omar & Qureshi & Muslim \\
\hline & & Nirupama & Vishwanath & General \\
\hline \multirow[t]{3}{*}{29} & \multirow{3}{*}{ Madras Café } & Major Vikram & Singh & General \\
\hline & & Jaya & Sahni & General \\
\hline & & Robin & Dutt & General \\
\hline \multirow[t]{3}{*}{30} & \multirow{3}{*}{ Ramaiya Vastavaiya } & Ram & & No Caste Affiliation \\
\hline & & Sona & & No Caste Affiliation \\
\hline & & Raghuveer & & No Caste Affiliation \\
\hline \multirow[t]{3}{*}{31} & \multirow{3}{*}{ Lootera } & Varun & Srivastav & General \\
\hline & & Pakhi Roy & Chaudhari & General \\
\hline & & A.K. & Bajpai & General \\
\hline \multirow[t]{3}{*}{32} & \multirow{3}{*}{ Mere Dad Ki Maruti } & Sameer & Khullar & General \\
\hline & & Jasleen & & No Caste Affiliation \\
\hline & & Tej & Khullar & General \\
\hline
\end{tabular}


Do Hindi Cinema \& Television Serials Propagate Caste Stereotypes through Surnames of Characters: A Content Analysis

\begin{tabular}{|c|c|c|c|c|}
\hline \multirow[t]{3}{*}{33} & \multirow{3}{*}{ Saheb Biwi Aur Gangster Returns } & Aditya Pratap & Singh & General \\
\hline & & IndrajeetPratap & Singh & General \\
\hline & & Madhavi & Devi & No Caste Affiliation \\
\hline \multirow[t]{3}{*}{34} & \multirow{3}{*}{ Ghanchakkar } & Sanjay & Atre & General \\
\hline & & Uttam & Nagpal & General \\
\hline & & Neetu & Atre & General \\
\hline \multirow[t]{3}{*}{35} & \multirow{3}{*}{ Akaash Vani } & Akaash & & No Caste Affiliation \\
\hline & & Vani & & No Caste Affiliation \\
\hline & & Ravi & & No Caste Affiliation \\
\hline \multirow[t]{3}{*}{36} & \multirow{3}{*}{ Ek Thi Daayan } & BejoyCharan & Mathur & General \\
\hline & & Tamara & & No Caste Affiliation \\
\hline & & Lisa & Dutt & General \\
\hline \multirow[t]{3}{*}{37} & \multirow{3}{*}{ Himmatwala } & Ravi & & No Caste Affiliation \\
\hline & & Rekha & & No Caste Affiliation \\
\hline & & Sher & Singh & General \\
\hline \multirow[t]{3}{*}{38} & \multirow{3}{*}{ Shree } & Shree & & No Caste Affiliation \\
\hline & & Sonu & & No Caste Affiliation \\
\hline & & Tilak & & No Caste Affiliation \\
\hline \multirow[t]{3}{*}{39} & \multirow{3}{*}{ Rangrezz } & Rishi & Deshpande & General \\
\hline & & Megha & Joshi & General \\
\hline & & Brijbihari & Pandey & General \\
\hline \multirow[t]{3}{*}{40} & \multirow{3}{*}{ Enemmy } & Yugandhar & Vishnoye & General \\
\hline & & Eklavya & Karmarkar & $\mathrm{OBC}$ \\
\hline & & Naeem & Shaikh & Muslim \\
\hline \multirow[t]{3}{*}{41} & \multirow{3}{*}{ Singh Sahab the Great } & Shikha & Chaturvedi & General \\
\hline & & Bhoodev & & No Caste Affiliation \\
\hline & & Saranjeet & Talwar & General \\
\hline \multirow[t]{3}{*}{42} & \multirow{3}{*}{ ABCD: Any Body Can Dance } & Vishnu & & No Caste Affiliation \\
\hline & & Jahangir & Khan & Muslim \\
\hline & & Gopi & & No Caste Affiliation \\
\hline
\end{tabular}

\section{Movies Released in 2014}

\begin{tabular}{|c|c|c|c|c|}
\hline 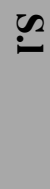 & 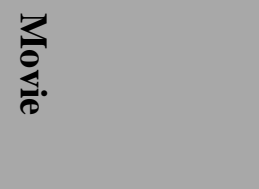 & 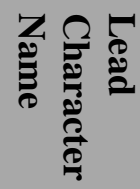 & $\stackrel{\infty}{E}$ & 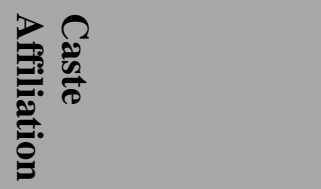 \\
\hline \multirow{4}{*}{1} & \multirow{4}{*}{ Gang of Ghosts } & Raju & Writer & No Caste Affiliation \\
\hline & & Director & & No Caste Affiliation \\
\hline & & Tania & & \\
\hline & & & & No Caste Affiliation \\
\hline
\end{tabular}


Do Hindi Cinema \& Television Serials Propagate Caste Stereotypes through Surnames of Characters: A Content Analysis

\begin{tabular}{|c|c|c|c|c|}
\hline \multirow{3}{*}{2} & \multirow{3}{*}{ Queen } & Rani & Mehra & General \\
\hline & & Vijay & & No Caste Affiliation \\
\hline & & Vijaylakshmi & & No Caste Affiliation \\
\hline \multirow{3}{*}{3} & \multirow{3}{*}{ Roy } & Roy & & General \\
\hline & & Kabir & Grewal & General \\
\hline & & Tia & Desai & General \\
\hline \multirow{3}{*}{4} & \multirow{3}{*}{ Creature } & Ahana & Dutt & General \\
\hline & & Karan & Malhotra & General \\
\hline & & Professor sadana & Sadana & General \\
\hline \multirow{3}{*}{5} & \multirow{3}{*}{ Action Jackson } & Vishi & & No Caste Affiliation \\
\hline & & Khushi & & No Caste Affiliation \\
\hline & & Anusha & & No Caste Affiliation \\
\hline \multirow{3}{*}{6} & \multirow{3}{*}{ Happy Ending } & Yudi & Jaitely & General \\
\hline & & Aanchal & Reddy & General \\
\hline & & Armaan & & No Caste Affiliation \\
\hline \multirow{3}{*}{7} & \multirow{3}{*}{ Ugly } & Rahul & Kapoor & General \\
\hline & & Shoumik & Bose & General \\
\hline & & Chaitanya & Mishra & General \\
\hline \multirow{3}{*}{8} & \multirow{3}{*}{ Bhoothnath Returns } & Khailash & Nath & No Caste Affiliation \\
\hline & & Bindia & Pathak & General \\
\hline & & Bhau & Sahib & No Caste Affiliation \\
\hline \multirow{3}{*}{9} & \multirow{3}{*}{ Finding Fanny } & Angelina & & No Caste Affiliation \\
\hline & & Savio & Gama & No Caste Affiliation \\
\hline & & Ferdinand & & No Caste Affiliation \\
\hline \multirow{3}{*}{10} & \multirow{3}{*}{ Raja Natwarlal } & Raja & & No Caste Affiliation \\
\hline & & Yogi & & No Caste Affiliation \\
\hline & & Varda & Yadav & $\mathrm{OBC}$ \\
\hline \multirow{3}{*}{11} & \multirow{3}{*}{ Kya Dilli Kya Lahore } & Rehmat & Ali & Muslim \\
\hline & & Samarth Pratap & Shastri & General \\
\hline & & Barfi & Singh & General \\
\hline \multirow{3}{*}{12} & \multirow{3}{*}{ Ankhon Dekhi } & Bauji & & No Caste Affiliation \\
\hline & & Rishi Chacha & & No Caste Affiliation \\
\hline & & Sharma ji & Sharma ji & General \\
\hline \multirow{3}{*}{13} & \multirow{3}{*}{ Total Siyapaa } & Aman & & No Caste Affiliation \\
\hline & & Rajinder & Singh & General \\
\hline & & Asha & & No Caste Affiliation \\
\hline \multirow{3}{*}{14} & \multirow{3}{*}{ The Shaukeens } & Lali & & No Caste Affiliation \\
\hline & & $\mathrm{KD}$ & & No Caste Affiliation \\
\hline & & Pinki & & No Caste Affiliation \\
\hline 15 & Наwаа Наwааі & Arjun Harishchand & Waghmare & General \\
\hline 15 & Hawaa Hawaaı & Aniket & Bhargava & General \\
\hline
\end{tabular}


Do Hindi Cinema \& Television Serials Propagate Caste Stereotypes through Surnames of Characters: A Content Analysis

\begin{tabular}{|c|c|c|c|c|}
\hline & & Aniruddha & Bhargava & General \\
\hline \multirow{3}{*}{16} & \multirow{3}{*}{ Gulab Gang } & Rajjo & & No Caste Affiliation \\
\hline & & Sumitra & Devi & No Caste Affiliation \\
\hline & & Kajri & & No Caste Affiliation \\
\hline \multirow{3}{*}{17} & \multirow{3}{*}{ Filmistaan } & Sunny & & No Caste Affiliation \\
\hline & & Aftab & & Muslim \\
\hline & & Mehmood & & Muslim \\
\hline \multirow{3}{*}{18} & \multirow{3}{*}{ Miss Lovely } & Sonu & & No Caste Affiliation \\
\hline & & Pinki & & No Caste Affiliation \\
\hline & & Vicky & & No Caste Affiliation \\
\hline \multirow{3}{*}{19} & \multirow{3}{*}{ Ungli } & Nikhil & Abhyankar & No Caste Affiliation \\
\hline & & Abhay & & No Caste Affiliation \\
\hline & & Maya & & No Caste Affiliation \\
\hline \multirow{3}{*}{20} & \multirow{3}{*}{ Bewakoofiyaan } & Mohit & Chadha & General \\
\hline & & Mayera & Sehgal & General \\
\hline & & VK & Sehgal & General \\
\hline \multirow{3}{*}{21} & \multirow{3}{*}{ Youngstaan } & Abhimanyu & Kaul & General \\
\hline & & Anwita & Chauhan & General \\
\hline & & Shubhodeep & Ganguly & General \\
\hline \multirow{3}{*}{22} & \multirow{3}{*}{ Revolver Rani } & Alka & Singh & General \\
\hline & & Rohan & Kapoor & General \\
\hline & & Udaybhan & Tomar & General \\
\hline \multirow{3}{*}{23} & \multirow{3}{*}{ Ya Rub } & Ran Vijay & Singh & General \\
\hline & & Amreen & & Muslim \\
\hline & & Ikram & & Muslim \\
\hline \multirow{3}{*}{24} & \multirow{3}{*}{ Heartless } & Aditya & Singh & General \\
\hline & & Shruti & Tandon & General \\
\hline & & Abhinav & velidi & General \\
\hline \multirow{3}{*}{25} & \multirow{3}{*}{ Dishkiyaoon } & Viki & Kartoos & No Caste Affiliation \\
\hline & & Meera & & No Caste Affiliation \\
\hline & & Nawab & Khan & Muslim \\
\hline \multirow{3}{*}{26} & \multirow{3}{*}{ Samrat\& Co. } & Samrat & Tilakdhari & General \\
\hline & & Dimpy & Singh & General \\
\hline & & Chakradhar & Pandey & General \\
\hline \multirow{3}{*}{27} & \multirow{3}{*}{ Darr@ the Mall } & Vishnu & Sharma & General \\
\hline & & Ahana & Manchanda & General \\
\hline & & Alok & Manchanda & General \\
\hline \multirow{3}{*}{28} & \multirow{3}{*}{ Kaanchi } & Kaanchi & & No Caste Affiliation \\
\hline & & Binda & & No Caste Affiliation \\
\hline & & Shyam & Kakra & General \\
\hline
\end{tabular}


Do Hindi Cinema \& Television Serials Propagate Caste Stereotypes through Surnames of Characters: A Content Analysis

\begin{tabular}{|c|c|c|c|c|}
\hline \multirow{3}{*}{29} & \multirow{3}{*}{ Ekkees Toppon Ki Salaami } & Purushotam Narayan & Joshi & General \\
\hline & & Taanya & Srivastav & General \\
\hline & & Subhash & Joshi & General \\
\hline \multirow{3}{*}{30} & \multirow{3}{*}{ Mastram } & Rajaram & & No Caste Affiliation \\
\hline & & Chacha & & No Caste Affiliation \\
\hline & & Renu & & No Caste Affiliation \\
\hline \multirow{3}{*}{31} & \multirow{3}{*}{ Kuku Mathur Ki Jhand Ho Gayi } & Kuku & Mathur & General \\
\hline & & Mitali & & No Caste Affiliation \\
\hline & & Rosi & & No Caste Affiliation \\
\hline \multirow{3}{*}{32} & \multirow{3}{*}{ Dekh Tamasha Dekh } & Muthaseth & & No Caste Affiliation \\
\hline & & Vishwasrao & & No Caste Affiliation \\
\hline & & Fatima & & Muslim \\
\hline \multirow{3}{*}{33} & \multirow{3}{*}{ Kill Dil } & Guru & & No Caste Affiliation \\
\hline & & Dev & & No Caste Affiliation \\
\hline & & Tutu & & No Caste Affiliation \\
\hline \multirow{3}{*}{34} & \multirow{3}{*}{ Fugly } & R.S. & Chautala & General \\
\hline & & Dev & & No Caste Affiliation \\
\hline & & Devi & & No Caste Affiliation \\
\hline \multirow{3}{*}{35} & \multirow{3}{*}{ Hate Story 2} & Mandar & Mhatre & General \\
\hline & & Sonika & Prasad & No Caste Affiliation \\
\hline & & Akshay & Bedi & General \\
\hline \multirow{3}{*}{36} & \multirow{3}{*}{ One by two } & Amit & Sharma & General \\
\hline & & Samara & patel & General \\
\hline & & Bunty & & No Caste Affiliation \\
\hline \multirow{3}{*}{37} & \multirow{3}{*}{ O Teri } & Prantabh & Pratab & No Caste Affiliation \\
\hline & & AnandIshwaramDevdutt & Subramanium & General \\
\hline & & Monsoon & & No Caste Affiliation \\
\hline \multirow{3}{*}{38} & \multirow{3}{*}{ The Xpose } & Ravi & Kumar & No Caste Affiliation \\
\hline & & Chandini & Raza & Muslim \\
\hline & & Kenny & Damania & General \\
\hline \multirow{3}{*}{39} & \multirow{3}{*}{ Kick } & Devi Lal & Singh & General \\
\hline & & Shaina & Mehra & General \\
\hline & & Himanshu & Tyagi & General \\
\hline \multirow{3}{*}{40} & \multirow{3}{*}{ PK } & Jagat Janani & Sahni & General \\
\hline & & Cherry & Bajwa & General \\
\hline & & Sarfaraz & Yousaf & General \\
\hline \multirow{3}{*}{41} & \multirow{3}{*}{ Happy New Year } & Mohini & Joshi & General \\
\hline & & Chandramohan Manohar & Sharma & General \\
\hline & & Vicky & Grover & General \\
\hline
\end{tabular}


Do Hindi Cinema \& Television Serials Propagate Caste Stereotypes through Surnames of Characters: A Content Analysis

\begin{tabular}{|c|c|c|c|c|}
\hline \multirow{3}{*}{42} & \multirow{3}{*}{ Bang Bang } & Jai & Nanda & General \\
\hline & & Harleen & Sahani & General \\
\hline & & Omar & Zafar & Muslim \\
\hline \multirow{3}{*}{43} & \multirow{3}{*}{ Gunday } & Bikram & Bose & General \\
\hline & & Bala & Bhattacharya & General \\
\hline & & Nandita & Sengupta & General \\
\hline \multirow{3}{*}{44} & \multirow{3}{*}{ Jai Ho } & Jai & Agnihotri & General \\
\hline & & Dashrat & Singh & General \\
\hline & & Geeta & Agnihotri & General \\
\hline \multirow{3}{*}{45} & \multirow{3}{*}{ Ek Villain } & Rakesh & Mahadkar & General \\
\hline & & Guru Pratap & Singh & General \\
\hline & & Aisha & Verma & OBC \\
\hline \multirow{3}{*}{46} & \multirow{3}{*}{ Singham } & Bajirao & Singham & General \\
\hline & & Avni & Kamat & General \\
\hline & & Satyaraj Chandra & Baba & No Caste Affiliation \\
\hline \multirow{3}{*}{47} & \multirow{3}{*}{ Dedh Ishqiya } & Begum & Para & Muslim \\
\hline & & Razzaakh & Hussain & Muslim \\
\hline & & Ifthekhar & & Muslim \\
\hline \multirow{3}{*}{48} & \multirow{3}{*}{2 States } & Krish & Malhotra & General \\
\hline & & Ananya & Swaminathan & General \\
\hline & & Kavita & Malhotra & General \\
\hline \multirow{3}{*}{49} & \multirow{3}{*}{ Hasee to Phasee } & Nikhil & Bharadwaj & General \\
\hline & & Dr.Meeta & Solanki & General \\
\hline & & Karishma & Solanki & General \\
\hline \multirow{3}{*}{50} & \multirow{3}{*}{ Highway } & Veera & Tripathi & General \\
\hline & & Mahabir & Bhati & General \\
\hline & & M. K. & Tripathi & General \\
\hline \multirow{3}{*}{51} & \multirow{3}{*}{ Yaariyan } & Lakshya & & No Caste Affiliation \\
\hline & & Saloni & & No Caste Affiliation \\
\hline & & Jiya & & No Caste Affiliation \\
\hline \multirow{3}{*}{52} & \multirow{3}{*}{ Haider } & Haider & & Muslim \\
\hline & & Arshia & Lone & Muslim \\
\hline & & Ghazala & Meer & Muslim \\
\hline \multirow{3}{*}{53} & \multirow{3}{*}{ Mardaani } & ShivaniShivaji & Roy & General \\
\hline & & Karan & Rastogi & General \\
\hline & & Sunny & Katyal & General \\
\hline \multirow{3}{*}{54} & \multirow{3}{*}{ Raagini MMS 2} & Sunny & Leone & No Caste Affiliation \\
\hline & & Satya & Kumar & No Caste Affiliation \\
\hline & & Rocks & & No Caste Affiliation \\
\hline 55 & Heronanti & Bablu & & No Caste Affiliation \\
\hline J & & Dimpi & & No Caste Affiliation \\
\hline
\end{tabular}


Do Hindi Cinema \& Television Serials Propagate Caste Stereotypes through Surnames of Characters: A Content Analysis

\begin{tabular}{|c|c|c|c|c|}
\hline & & Chaudhary & & No Caste Affiliation \\
\hline \multirow{3}{*}{56} & \multirow{3}{*}{ Bobby Jasoos } & Bilkis & Ahmed & Muslim \\
\hline & & Tasawur & & Muslim \\
\hline & & Naeem & & Muslim \\
\hline \multirow{3}{*}{57} & \multirow{3}{*}{ Shadi Ke Side Effects } & Siddharth & Roy & General \\
\hline & & Trisha & Roy & General \\
\hline & & Ranveer & & No Caste Affiliation \\
\hline \multirow[b]{3}{*}{58} & \multirow{3}{*}{ Mai Tera Hero } & Srinath & Prasad & General \\
\hline & & Angad & Negi & General \\
\hline & & Ayesha & Saigal & General \\
\hline \multirow{3}{*}{59} & \multirow{3}{*}{ Humpty Sharma Ki Dulhaniya } & Rakesh 'Humpty’ & Sharma & General \\
\hline & & KavyaPratap & Singh & General \\
\hline & & Angad & & No Caste Affiliation \\
\hline \multirow{3}{*}{60} & \multirow{3}{*}{ Daawat-e-Ishq } & Gulrez & & Muslim \\
\hline & & Tariq "Taru" & Haidar & Muslim \\
\hline & & Abdul & Qadir & Muslim \\
\hline \multirow{3}{*}{61} & \multirow{3}{*}{ Entertainment } & Akhil & Lokhande & General \\
\hline & & Saakshi & & No Caste Affiliation \\
\hline & & Karan & & No Caste Affiliation \\
\hline \multirow{3}{*}{62} & \multirow{3}{*}{ Holiday } & Virat & & No Caste Affiliation \\
\hline & & Saiba & Thapar & General \\
\hline & & Mukund & Deshmukh & General \\
\hline \multirow{3}{*}{63} & \multirow{3}{*}{ Khoobsurat } & Dr Mrinalini "Milli" & Chakravarty & General \\
\hline & & Vikram Singh & Rathore & General \\
\hline & & Manju & Chakravarty & General \\
\hline \multirow{3}{*}{64} & \multirow{3}{*}{ City Lights } & Deepak & Singh & General \\
\hline & & Vishnu & & No Caste Affiliation \\
\hline & & Sudha & & No Caste Affiliation \\
\hline
\end{tabular}

